concerned with the conservation of biodiversity... It has addressed often neglected topics or groups of species and some of its projects have had considerable success in often challenging situations'.

Since 1992756 projects have been funded by the Darwin Initiative in 155 countries. The focus and scope of these projects varies from micro fungi to whale sharks, and from Arctic ecosystems to tropical peat forests. The one variable these projects have in common is scientific rigour, as demonstrated by the 2,225 peer reviewed articles produced by the projects, and the capacity built in developing countries to meet their commitments under the three biodiversity conventions (CBD, CITES and CMS; 394 Masters and ${ }_{151} \mathrm{PhDs}$ completed).

The Darwin Initiative's impact is, however, measured by more than its academic outputs. The critical measure is the success it has had in biodiversity conservation. Examples include the establishment of a second population of the Seychelles paradise flycatcher on La Digue in the Seychelles, work undertaken to reduce the decline of vultures in India, Nepal and Pakistan, and strengthening of protected area management and support to indigenous groups to govern their natural resources. The Initiative has also been the funder of numerous discoveries, including new taxa such as the dung beetle Canthidium darwini (Kohlmann \& Solis, 2009, Zootaxa, 2219, 31-37), the orchid Lagopsis darwiniana (Pyak et al., 2007, Kew Bulletin, 62, 107-111) and a genus, Darwininitium, of land snail (Budha et al., 2012, ZooKeys, 175, 19-26.).

The UK Government's support for the Darwin Initiative is critical for its success and, throughout the last 20 years, regardless of political persuasion, governments have universally supported it. The Initiative has now retained its commitment from the UK Government for a further term despite the current economic climate. Additional funding from the Department for International Development (DFID), in particular, has secured the survival of the Initiative for the next few years.

The addition of DFID funding to the Darwin Initiative brings with it another change in emphasis to project funding: economic development. Economic benefits to local communities and poverty alleviation in developing countries have often been outcomes of successful Darwin Initiative projects because of the inextricable links between biodiversity and livelihoods. From 2012, however, economic benefits will receive more focus, particularly with reference to the driving forces behind biodiversity loss. DFID's core mandate is enshrined in the UK's 2007 International Development Act, with all projects funded by DFID required to meet the requirements of Official Development Assistance. Projects must directly enhance the welfare and economic development of poor people in low income countries. A new funding round for the Darwin Initiative is expected in summer 2012, in which the focus on economic development and human welfare in low income countries will become apparent. To find out more about the Darwin Initiative visit http://www.defra.gov.uk/darwin

LESLEY KING LTS International, Edinburgh, UK

E-mail lesley-king@ltsi.co.uk

CHRISTA WILD Defra, London, UK

\section{A rhino success story in West Bengal, India}

Conservation efforts for the greater one-horned rhino in the State of West Bengal, India, have been exemplary, as we learned during a visit there in February 2012. Rhino numbers have been steadily rising in both the $80 \mathrm{~km}^{2}$ Gorumara National Park and $216 \mathrm{~km}^{2}$ Jaldapara Wildlife Sanctuary. In 1985 there were only eight rhinos in Gorumara and 14 in Jaldapara but by the 2004 census they had reached 25 and 96, and there are now 40 and 150 rhinos in these two protected areas, respectively. From 1994 to 2011 only nine rhinos were recorded to have been poached in West Bengal. Jaldapara is now home to the third largest rhino population in Asia. This is a major success story at a time when most news about rhinos has been desperately bad, especially from Vietnam, Cameroon, South Africa and Zimbabwe. What can other countries learn about rhino protection from this little-known region that receives so few foreign visitors and little foreign or NGO assistance?

Both the Central and State governments have put generous and well-allocated funds into Gorumara and Jaldapara: over USD 5,000 per $\mathrm{km}^{2}$ per year, one of the highest for any government rhino protected area. This permits the unusually high figure of more than one person per $\mathrm{km}^{2}$ for patrolling and habitat management and considerable resources for local communities. West Bengal officials recognize that rhinos are a cultural heritage of the State and attract many Indian tourists. They are also aware that to save rhinos the local people must receive direct benefits.

The State government's Forest Department has established numerous eco-development projects benefiting the villagers that live on the fringes of these protected areas. Eco-development committees hold regular meetings with forest staff to discuss how to spend funds. Additional money comes from a percentage of the tourist revenue received from the two protected areas. The Forest Department has set up eco-lodges that employ local staff and has established other tourist enterprises, such as handicraft making and demonstrations of tribal dancing, to bring money to the villagers. To deter people from relying on the forest officials have encouraged other livelihoods such as tailoring and piggeries. The government provides funding for injury and death caused by large animals, and there is also compensation for damage to crops, livestock and houses, which is not always the case in India. The Department also provides 
employment for villagers in the protected areas, as guides and jeep drivers, for example. Both Gorumara and Jaldapara also hire many local people part-time. The villagers assist when needed, including in anti-poaching, fire control and providing information on potential poachers.

The villagers understand that if the forest and its animals are well protected they will receive greater benefits from the Forest Department. 'If the people protect the jungle and its animals, they can be sustained by it', explained a Range Officer in Gorumara who gives the villagers regular talks about the benefits of conserving rhinos and the forest. He acknowledged that having thousands of pairs of eyes around Gorumara and Jaldapara provides the best wall of protection. Although the region is close to the porous borders with Nepal, Bhutan and China, foreign poachers are rarely able to penetrate this barrier of local people. The villagers are a close-nit community who want to protect their rhinos. The forest staff have carried out awareness campaigns on rhino conservation, and effective management in the Forest Department has boosted staff morale and motivation. Mobile phones have strengthened the information gathering process (cf. Oryx, 46, 137-144), helping to prevent poaching more effectively. The Department's activities are transparent, whereby anyone, including forest guards, can contact senior staff to report corruption, and the media is active in reporting misdemeanours. Officials follow up on such reports. Penalties for illegal killing of wildlife and trading in wildlife products are sufficient and often implemented.

Despite the high export price for rhino horn of c. USD $13,000 \mathrm{~kg}^{-1}$, rhino poaching is now under control in West Bengal because of ever-improving vigilance. It is a success story from which other rhino range states can learn that the concept 'man management is the best management for protected areas' actually works, by winning the confidence and trust not only of the staff but also of the local people.

LuCy Vigne and Esmond Martin PO Box 15510, Nairobi 00503, Kenya

E-mailrhino@wananchi.com

\section{Conservation Leadership Programme announces 2012 awards}

The Conservation Leadership Programme (CLP) supports exceptionally talented, early-career conservationists who are striving to safeguard threatened species and habitats worldwide. In April the CLP announced the winners of its annual awards and granted c. USD 490,500 to 28 projects in 22 countries. Of these, 24 are new projects, two are Followup projects and two are Conservation Leadership Awards that provide substantial resources to first-rate innovative and original projects previously supported by the
Programme. This year the newly funded projects range from classic research projects (e.g. Population trends of marmosets in the Brazilian Amazon) to youth work aimed at improving attitudes towards Amur tigers in Russia, and capacity building among coastal fishing groups in Kenya. The two top awards, each worth USD 50,000, were won by a Cuban project to promote the conservation of the island's plant life, and a Colombian project to protect important habitat for the Critically Endangered Niceforo's wren and Endangered chestnut-bellied hummingbird. To view a full list of funded projects visit http://www.conservationleadershipprogramme.org/projects.asp. A representative from each award-winning team recently took part in CLP's Conservation Management \& Leadership Training Workshop at a remote ecological research station in the foothills of the Canadian Rockies. The workshop covered topics such as project planning, behaviour change through education and outreach, media training, climate change and fund-raising. Beyond the project funding and training, each award-winning team member will join a network of over 3,500 CLP alumni. This network helps awardees implement conservation projects and carry out research in often challenging and isolated environments. Alumni members also receive access to additional grants, specialized training courses and mentoring from CLP staff and conservation experts. The Programme was initiated in 1985 and is a partnership between Fauna \& Flora International, BirdLife International, Conservation International and the Wildlife Conservation Society. See p. 466 for the call for applications for the 2013 awards.

Stuart Paterson Conservation Leadership Programme, Fauna \& Flora International, Cambridge, UK

E-mail stuart.paterson@fauna-flora.org

\section{9th annual Whitley Awards}

The 19th annual Whitley Awards Ceremony was held on 9 May 2012 at the Royal Geographical Society in London. The flagship event of UK-based charity the Whitley Fund for Nature was hosted by writer and broadcaster John McCarthy, and saw seven conservation leaders from seven different countries receive Whitley Awards worth GBP 30,000 each in project funding over 1 year in support of their work. In addition, a special Whitley Gold Award was presented to 2004 Whitley Award winner Rodrigo Medellin of Mexico for his outstanding contribution to the conservation of bats in Latin America with the help of Continuation Funding from WFN. Over 400 people attended the event, where the charity's patron, HRH The Princess Royal, presented the Awards. The 2012 Whitley Award Winners are: Joanna Alfaro Shigueto, Peru (Conservation of threatened marine fauna through sustainable coastal fisheries); Inza Koné, Ivory Coast 